\title{
Conducting two-phase silicon oxide layers for thin-film silicon solar cells
}

\author{
Peter Buehlmann ${ }^{1}$, Julien Bailat ${ }^{2}$, Andrea Feltrin ${ }^{1}$, Christophe Ballif ${ }^{1}$ \\ ${ }^{1}$ IMT, University of Neuchâtel, Neuchâtel, Switzerland \\ ${ }^{2}$ Now at Oerlikon Solar-Lab, Neuchâtel, Switzerland
}

\begin{abstract}
We present optical properties and microstructure analyses of hydrogenated silicon suboxide layers containing silicon nanocrystals $\left(\mathrm{nc}_{-} \mathrm{SiO}_{\mathrm{x}}: \mathrm{H}\right)$. This material is especially adapted for the use as intermediate reflecting layer (IRL) in micromorph silicon tandem cells due to its low refractive index and relatively high transverse conductivity. The $\mathrm{nc}_{-}-\mathrm{SiO}_{\mathrm{x}}: \mathrm{H}$ is deposited by very high frequency plasma enhanced chemical vapor deposition from a $\mathrm{SiH}_{4} / \mathrm{CO}_{2} / \mathrm{H}_{2} / \mathrm{PH}_{3}$ gas mixture. We show the influence of $\mathrm{H}_{2} / \mathrm{SiH}_{4}$ and $\mathrm{CO}_{2} / \mathrm{SiH}_{4}$ gas ratios on the layer properties as

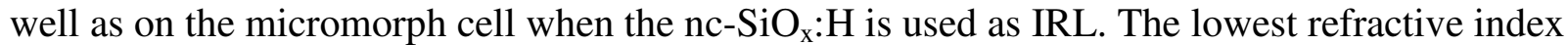
achieved in a working micromoph cell is 1.71 and the highest initial micromoph efficiency with such an IRL is $13.3 \%$.
\end{abstract}

\section{INTRODUCTION}

Thin film silicon technologies have a high potential for further cost reduction of terrestrial photovoltaics for energy production. In this technology, multi-junction solar cells are candidate to achieve efficiencies comparable to the well established crystalline silicon solar cells. One of the most promising structures is the micromorph cell where a high band-gap amorphous top cell and a low band-gap microcrystalline bottom cell are stacked upon each other to better exploit the solar spectrum. The individual cells composing a multi-junction cell are electrically connected in series and special care has therefore to be taken to match their currents. Matching of currents can be achieved by adjusting the thickness of the thin absorber layers or by the insertion of an intermediate reflecting layer (IRL). The second solution is especially interesting for the micromorph cell where the top cell has to be kept reasonably thin $(<300 \mathrm{~nm})$ to limit the effects of the light induced Staebler-Wronski degradation of the amorphous material [1]. For high reflectivity, the IRL should have a refractive index (n) as low as possible whereas for the electrical requirements, the IRL must have a transverse conductivity of at least $10^{-5} \mathrm{~S} / \mathrm{cm}$ to avoid blocking the device. Very low in-plane conductivity is desired to avoid series interconnection of shunts in the elementary cells. The first results on micromorph cells with IRL were presented in 1996 by D. Fischer [2] who used $\mathrm{ZnO}$ as low-n material. Later a different approach was introduced by K. Yamamoto [3] without specifying the material used. In this study we will investigate on the use of $\mathrm{n}$-doped, hydrogenated silicon sub-oxide containing silicon nanocrystals ( $\left.\mathrm{nc}-\mathrm{SiO}_{\mathrm{x}}: \mathrm{H}\right)$ as proposed by our group [4] and A. Lambertz [5] in 2007.

\section{EXPERIMENTAL DETAILS}

The $\mathrm{n}$ doped $\mathrm{nc}-\mathrm{SiO}_{\mathrm{x}}: \mathrm{H}$ films were prepared from a mixture of $\mathrm{SiH}_{4}, \mathrm{CO}_{2}, \mathrm{H}_{2}$ and $\mathrm{PH}_{3}$ gases in a capacitively coupled very high frequency plasma enhanced chemical vapor deposition (VHF-PECVD) system. In this study all the $\mathrm{SiO}_{\mathrm{x}}$ layers were deposited at a pressure of $0.7 \mathrm{mbar}$, 
at a frequency of $110 \mathrm{MHz}$, with a power density of $0.1 \mathrm{~W} / \mathrm{cm}^{2}$, a constant $\mathrm{PH}_{3} / \mathrm{SiH}_{4}$ gas ratio of 0.1 and a deposition time sufficient to reach a layer thickness of $\sim 90 \mathrm{~nm}$. Ellipsometry, Raman scattering and thickness measurements were performed on layers deposited on glass. Refractive index (n) was found from fitting the ellipsometry measurements to a Tauc-Lorentz dispersion model including a surface roughness layer. The thickness was measured with a height profiler. Infrared (IR) absorption measurements were performed with a Nicolet 8700 system from Thermo on samples deposited on intrinsic, one-side polished wafers. The absorption spectra were normalized with the layer thickness.

The amorphous and microcrystalline cells were prepared by PECVD. Glass covered with rough CVD $\mathrm{ZnO}$ was used as substrate for the micromorph cells. CVD $\mathrm{ZnO}$ was used as back contact and teflon as diffusive back reflector. The cells were fully patterned to a size of $1.2 \mathrm{~cm}^{2}$. The short-circuit current density $\left(\mathrm{J}_{\mathrm{sc}}\right)$ of the solar cells was calculated from the measurement of the external quantum efficiency (EQE) curve, by integrating, over the wavelength range from 350 to $1100 \mathrm{~nm}$, the product of EQE times the incoming photon flux of the AM1.5g solar spectrum. The current-voltage curves were measured under a dual lamp WACOM solar simulator in standard test conditions $\left(25^{\circ} \mathrm{C}, \mathrm{AM} 1.5 \mathrm{~g}\right.$ spectrum, and $\left.1000 \mathrm{~W} / \mathrm{m}^{2}\right)$.

\section{RESULTS}

In this study, we present $\mathrm{nc}-\mathrm{SiO}_{\mathrm{x}}$ layers from three different gas ratio series. In the series $\mathrm{H} 100$ and $\mathrm{H} 300$, we varied the $\mathrm{CO}_{2} / \mathrm{SiH}_{4}$ between 1 and 3.5 with a constant $\mathrm{H}_{2} / \mathrm{SiH}_{4}$ gas flow ratio of 100 and 300 respectively. In series $\mathrm{C} 2.5$, the $\mathrm{H}_{2} / \mathrm{SiH}_{4}$ was varied from 100 to 400 with a constant $\mathrm{CO}_{2} / \mathrm{SiH}_{4}$ gas ratio of 2.5. Figure 1 compares the growth rates of all the nc-SiO $\mathrm{x}_{\mathrm{x}}$ layers from these three series.



Figure 1. Growth rates of $\mathrm{nc}-\mathrm{SiO}_{\mathrm{x}}$ layers from the three series: $\mathrm{H} 100, \mathrm{H} 300$ and $\mathrm{C} 2.5$

Figure $2 \mathrm{a}$ shows the IR absorption spectra of the H100 series. The peaks at $\sim 1050 \mathrm{~cm}^{-1}$ and between 800 and $900 \mathrm{~cm}^{-1}$ which have been reported to stem from the Si-O-Si stretching and bending modes $[6,7]$ increase with increasing $\mathrm{CO}_{2} / \mathrm{SiH}_{4}$ gas ratio. The oxygen content increases in a similar manner when the $\mathrm{H}_{2} / \mathrm{SiH}_{4}$ is increased from 100 to 300 with a fixed $\mathrm{CO}_{2} / \mathrm{SiH}_{4}$ of 2.5 as it can be seen on figure $2 b$. 

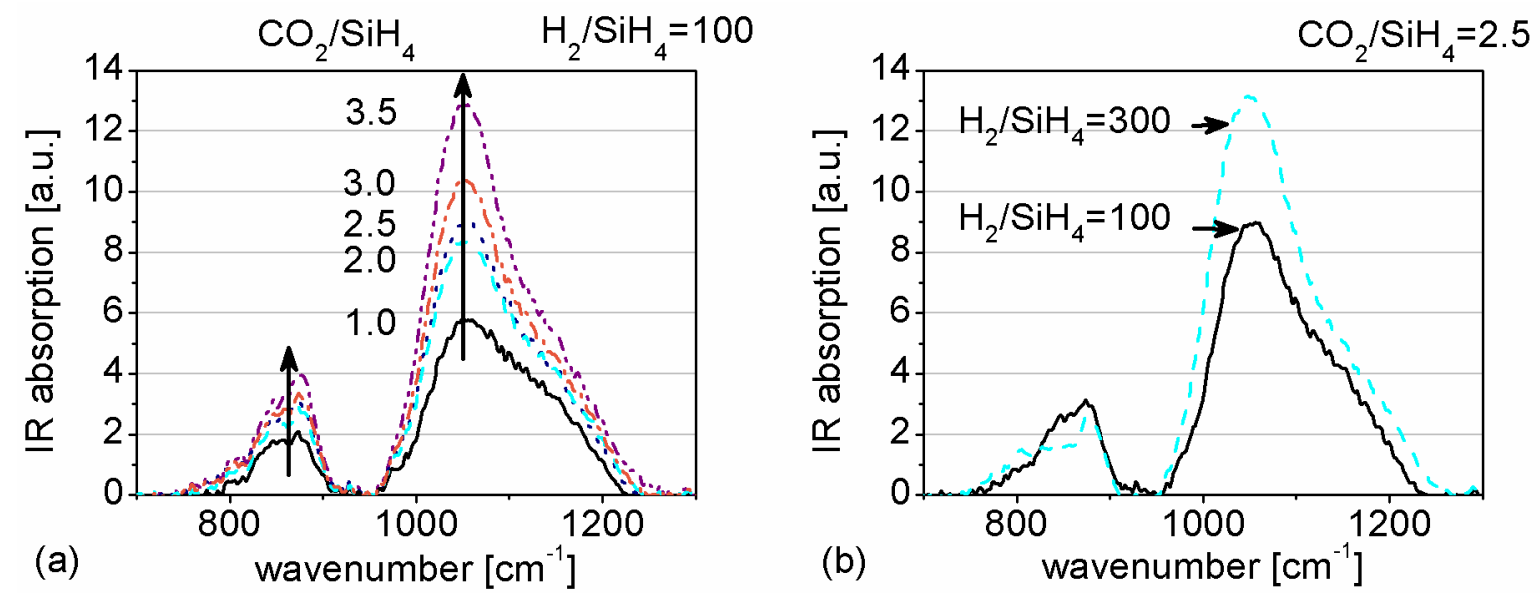

Figure 2. Infrared absorption spectra of the $\mathrm{H} 100$ series (a) and the comparison of two spectra with $\mathrm{CO}_{2} / \mathrm{SiH}_{4}$ gas ratio of 2.5 but different $\mathrm{H}_{2} / \mathrm{SiH}_{4}$ gas ratios (b).

Figure $3 \mathrm{a}$ and $3 \mathrm{~b}$ show the refractive index of the $\mathrm{nc}-\mathrm{SiO}_{\mathrm{x}}$ layers as a function of $\mathrm{CO}_{2} / \mathrm{SiH}_{4}$ and $\mathrm{H}_{2} / \mathrm{SiH}_{4}$ gas ratios. For the series $\mathrm{H} 100$ and $\mathrm{H} 300$, the $\mathrm{n}$ decreases with increasing $\mathrm{CO}_{2} / \mathrm{SiH}_{4}$ gas ratio. The same effect is also observed for the $\mathrm{C} 2.5$ series with increasing $\mathrm{H}_{2} / \mathrm{SiH}_{4}$ gas ratio. This tendency has been described by Iftiquar [6] who suggested that the main mechanism of oxygen incorporation in $\mathrm{SiO}_{\mathrm{x}}$ films deposited by PECVD is through the formation of O-H complexes in the plasma which more easily get to the growing layer surface than the highly reactive and electronegative atomic oxygen.
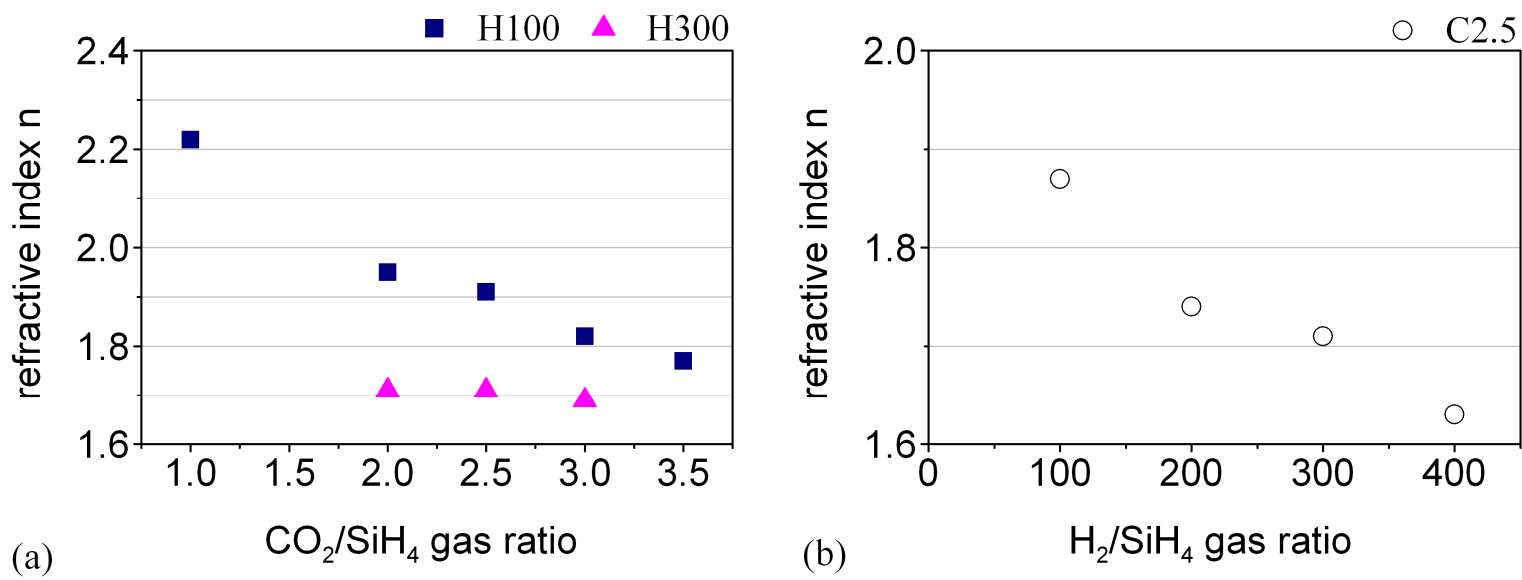

Figure 3. Refractive index (n) of $n c-\mathrm{SiO}_{\mathrm{x}}$ layers from the series: $\mathrm{H} 100, \mathrm{H} 300$ (a) and C2.5 (b)

To gain further insight into structural properties of the $n c-\mathrm{SiO}_{\mathrm{x}}$ layers we performed Raman scattering measurements and calculated the Raman crystalline fraction in the silicon phase [8]. Since the measurements don't account for the SiO, which is the dominant phase in our layers, the signal represents in this case not a crystalline volume fraction of the layer, but only the ratio of crystalline silicon signal over the crystalline plus amorphous silicon signal. The Raman scattering signal is very noisy because there is only little silicon phase remaining in our films. Figure 4a shows the Raman spectra of the H100 series. Figure 4b and 4c show the calculated Raman crystalline fraction in the silicon phase, and the total Raman silicon signal intensity as a function of $\mathrm{CO}_{2} / \mathrm{SiH}_{4}$ gas ratio for the $\mathrm{H} 100$ and $\mathrm{H} 300$ series. The crystalline 
fraction decreases with increasing $\mathrm{CO}_{2} / \mathrm{SiH}_{4}$ gas ratio whereas the total silicon Raman signal intensity remains almost constant. The total Raman peak intensity of the H100 series is almost twice as high as for the series H300 for comparable crystalline fractions. Based on these data, increasing $\mathrm{CO}_{2} / \mathrm{SiH}_{4}$ seems to convert the crystalline silicon to amorphous silicon without reducing the presence of the silicon phase whereas an increased $\mathrm{H}_{2} / \mathrm{SiH}_{4}$ seems to reduce the presence of silicon phase significantly.
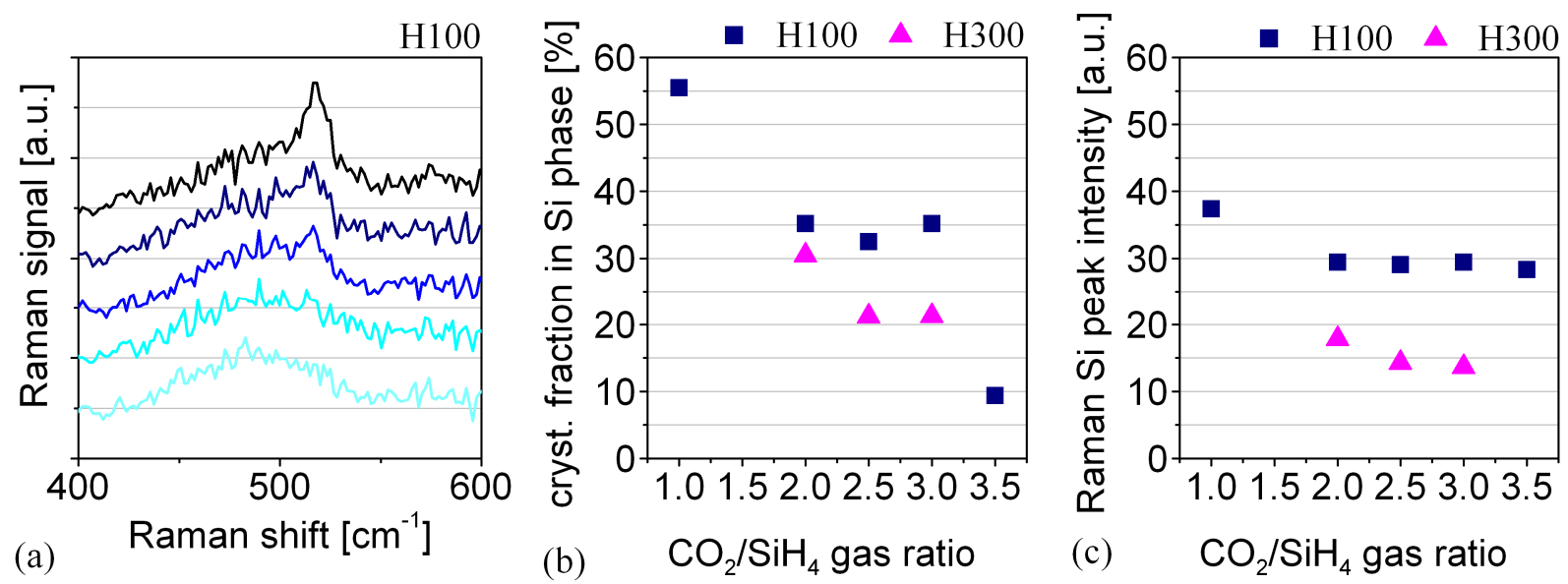

Figure 4. Raman spectra of the H100 series (a), Raman crystalline fraction in the silicon phase (b) and total Raman silicon peak intensity (c) of the H100, H300 and C2.5 series.

\section{DISCUSSION}

When the $\mathrm{nc}_{-} \mathrm{SiO}_{\mathrm{x}}$ layers are used as intermediate reflectors in micromorph cells, a sufficiently high transverse conductivity is needed to avoid blocking the device. If a $100 \mathrm{~nm}$ thick layer should not increase the series resistance in the micromorph cell more than $1 \mathrm{Ohm} \cdot \mathrm{cm}^{2}$, we can calculate a lower limit of the conductivity of $10^{-5} \mathrm{~S} / \mathrm{cm}$. On all the layers presented above we measured in-plane conductivities below this value. Figure 5 shows the current density-voltage (JV) curves of top-limited micromorph cells with the $\mathrm{nc}_{-} \mathrm{SiO}_{\mathrm{x}}$ layers from the $\mathrm{H} 100$ and the $\mathrm{H} 300$ series. $\mathrm{J}_{\mathrm{sc}}$ increases with decreasing $\mathrm{n}$ of the silicon oxide based intermediate reflector (SOIR) and there are cells with no increase of series resistance due to the SOIR with $\mathrm{n}$ as low as 1.71 although the measured in-plane conductivity of most $\mathrm{SiO}_{\mathrm{x}}$ layers is below $10^{-10} \mathrm{~S} / \mathrm{cm}$, which is the lower limit of our measurement system. From figure 4 we can assume that the in-plane conductivity is mostly determined by the highly resistive amorphous $\mathrm{SiO}_{\mathrm{x}}$ matrix whereas we belief that silicon nanocrystals are responsible for a relatively high transverse conductivity as observed in the micromorph cells. 


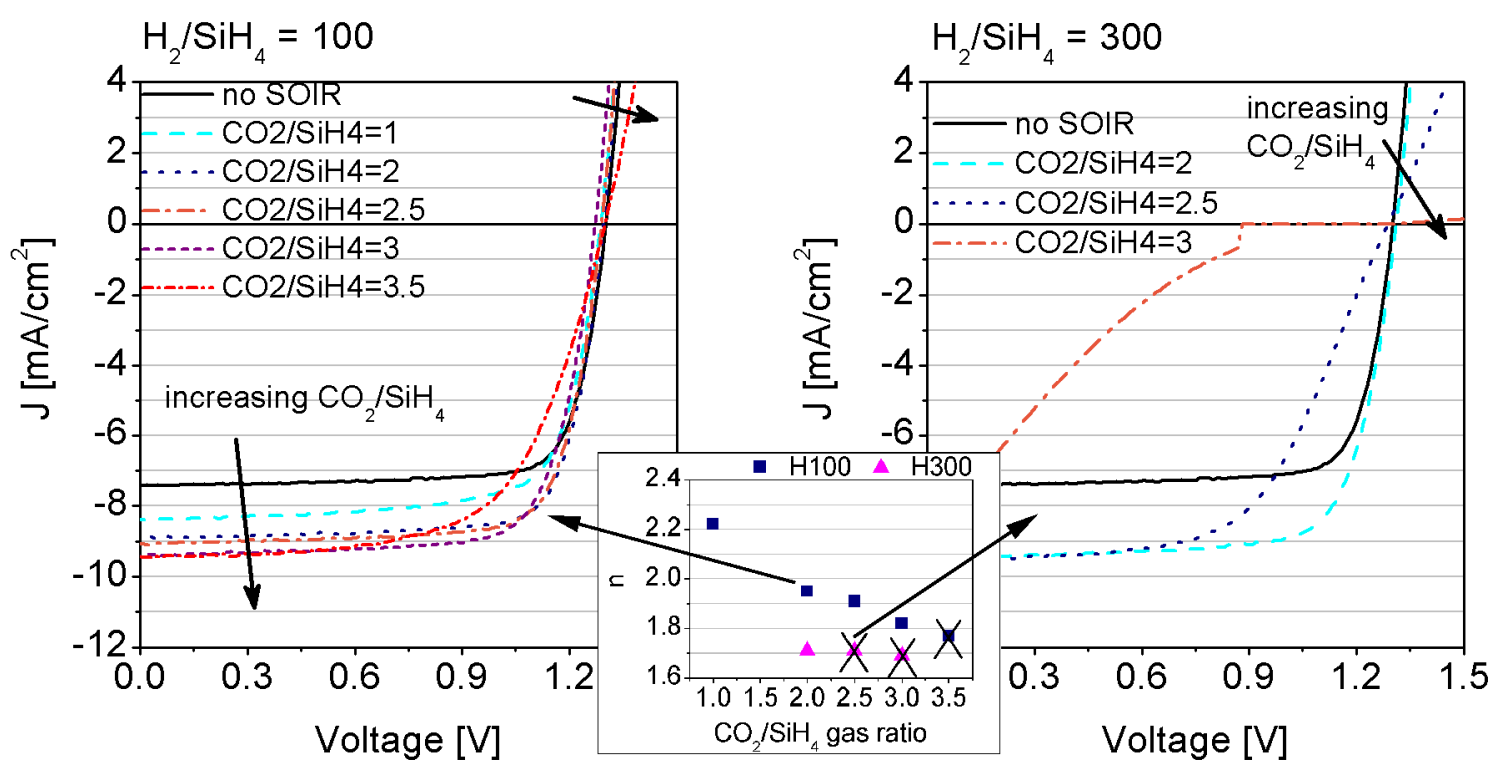

Figure 5. J-V curves of top-limited micromorph solar cells with the different SOIR from the H100 and H300 series. The inset shows the refractive index of the SOIR. SOIR that caused an increase of series resistance in cell are marked with a cross).
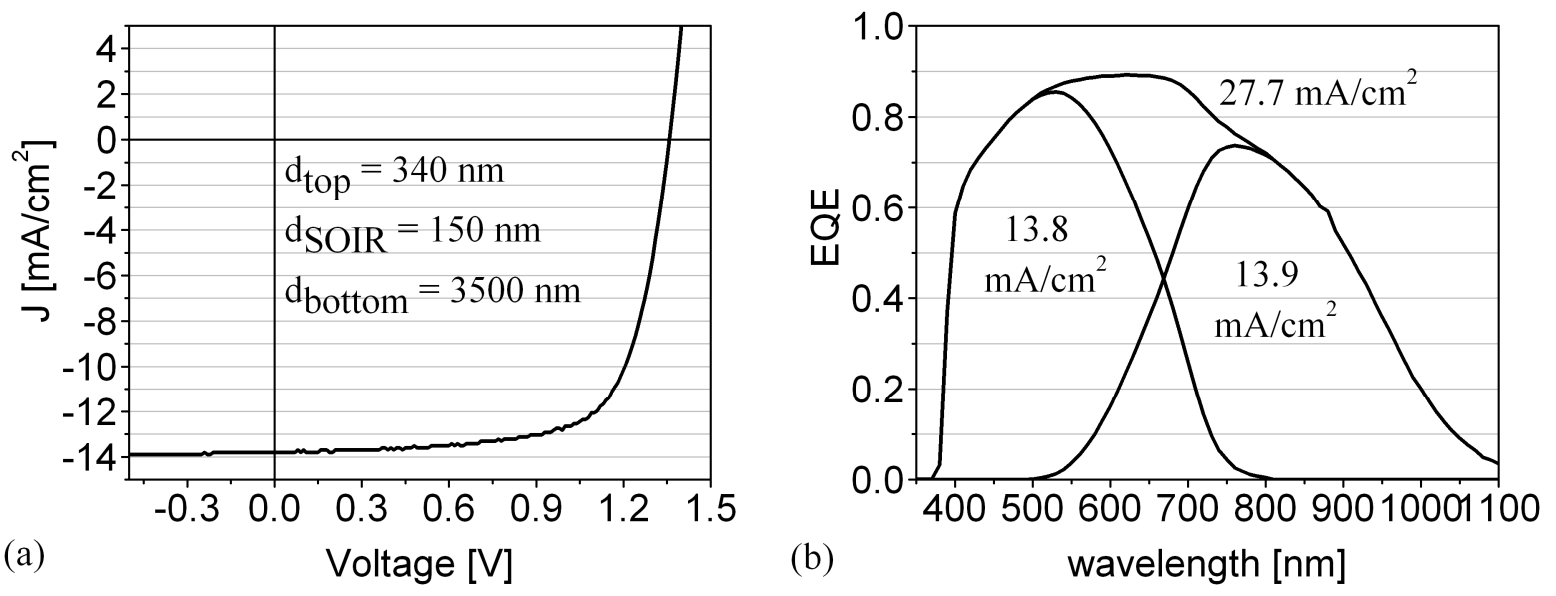

Figure 6. J-V (a) and EQE (b) curves of micromorph cell with $13.3 \%$ initial efficiency (Cell fully patterned to $1.2 \mathrm{~cm}^{2}$; with broadband anti-reflection coating on glass; $\mathrm{V}_{\mathrm{oc}}=1.36 \mathrm{~V}$,

$$
\mathrm{FF}=70.8, \mathrm{~J}_{\mathrm{sc}}=13.8 \mathrm{~mA} / \mathrm{cm}^{2} \text { ) }
$$

The SOIR with the lowest refractive index $(\mathrm{n}=1.71)$ without deteriorating the series resistance of the micromoph cell is deposited with $\mathrm{CO}_{2} / \mathrm{SiH}_{4}=2$ and $\mathrm{H}_{2} / \mathrm{SiH}_{4}=300$. Figure 6 shows an optimized micromorph cell, where the use of a SOIR has lead to a best initial efficiency of $13.3 \%$ with top cell, SOIR, bottom cell thicknesses of 340, 150, $3500 \mathrm{~nm}$ respectively [9].

\section{CONCLUSIONS}

We presented in this study nc-SiO layers with refractive indexes as low as 1.71 that can be used as SOIR in micromorph cells without compromising its series resistance. From optical 
measurements of the layers and from the results of the same layers incorporated as intermediate reflectors in micromorph cells we conclude that the high $\mathrm{H}_{2}$ dilution is important to get low refractive index material with sufficiently high transversal conductivity. Finally we showed an optimized micromorph cell with an initial efficiency of $13.3 \%$ with top cell, SOIR, bottom cell thicknesses of 340, 150, $3500 \mathrm{~nm}$ respectively.

\section{ACKNOWLEDGMENTS}

The authors gratefully acknowledge the support of the Swiss Federal Energy Office (OFEN) (project 101191) and the EU (Athlet Project, contract 019670).

\section{REFERENCES}

1. M. S. Bennett, J. L. Newton, and K. Rajan, Proceedings of the 7th European Photovoltaic Solar Energy Conference, Sevilla, Spain (Reidel, Dordrecht, 1987), pp. 544-548.

2. D. Fischer et al. in proceedings of the 25th IEEE Photovoltaic Specialists Conference, Washington D. C., USA (IEEE, New York, 1996), pp. 1053-1056.

3. K. Yamamoto et al., Solar Energy 77 (2004) pp. 939-949.

4. P. Buehlmann et al., Appl. Phys. Lett. 91, 143505 (2007).

5. A. Lambertz et al., 22th European Photovoltaic Solar Energy Conference, Milan, Italy (WIP, Munich, 2007), pp. 1839-1842.

6. S. M. Iftiquar, J. Phys. D: Appl. Phys. 31, 1630 (1998); High Temperature Material Processes, 6 (2002)

7. G. Lucovsky et al., Phys. Rev. B 28, 3225 (1983); Sol. En. Mat. 8, 165 (1982).

8. C. Droz, E. Vallat-Sauvain, J. Bailat, L. Feitknecht, and A. Shah, Proceedings of 17th European Photovoltaic Solar Energy Conference, Munich, Germany (WIP, Munich, 2002), pp. 2917-2920.

9. D. Dominé et al., 23th European Photovoltaic Solar Energy Conference, Valencia, Spain (WIP, Munich, 2008), pp. 2091-2095. 